\title{
High levels of Mercury and Lead detected by hair analysis in two Venezuelan environments
}

\author{
Eunice MARCANO ${ }^{1}$, Mary LABADY', Clara GOMES ${ }^{1}$, Guillermina AGUIAR ${ }^{1}$, Jorge LAINE ${ }^{1,2}$ \\ ABSTRACT \\ Mercury and Lead concentrations obtained by ICP-OAS analysis of human hair from riverside communities along the \\ Orinoco river in the Amazon state (Venezuela) were compared with those from Caracas, Venezuela. Taking into account the \\ characteristics of these two environments and the values of the average concentrations of Mercury and Lead, baselines were \\ established suggesting that gold mining activity near the Orinoco river is responsible for the high levels of Mercury in hair \\ from the Amazon state, whereas automobile activity is responsible for high levels of Lead in hair in Caracas.
}

KEY WORDS: Human hair, Hair analysis, Lead pollution, Mercury pollution, Environmental exposure.

\section{Altos níveis de Mercúrio e Chumbo detectados pela análise de cabelo em dois ambientes venezuelanos}

\section{RESUMO}

Concentrações de mercúrio e chumbo obtidas pela análise ICP-OAS de amostras de cabelo humano de comunidades ribeirinhas ao longo do rio Orinoco no estado de Amazonas (Venezuela) foram comparadas com outras de Caracas, Venezuela. Levando em consideração as características desses dois ambientes e os valores das concentrações médias de mercúrio e chumbo, foram estabelecidas linhas basais que sugerem que as atividades de minério de ouro próximo ao rio Orinoco são responsáveis pelos altos conteúdos de mercúrio em cabelo no estado de Amazonas. Entretanto, a indústria automotriz é responsável pelo alto conteúdo de chumbo em cabelo em Caracas.

Palavras-chave: Cabelo humano, Análise de cabelo, Contaminação por mercúrio, Contaminação por chumbo, Exposição ao ambiente.

\footnotetext{
${ }^{1}$ Centro de Química, Instituto Venezolano de Investigaciones Científicas, Apt. 20632, Caracas 1020-A, Venezuela

2 Corresponding author E-mail: jlaine@ivic.ve
} 


\section{INTRODUCTION}

The usefulness of hair analysis to monitor exposure to toxic metals such as Mercury and Lead has been well established (Taylor, 1986; Katz, 1992; Contiero \& Folin, 1994; Bencko, 1995; Hac \& Krechniak, 1996). Indeed, hair can reflect the long-term cumulative body pool of many elements better than either blood or urine. Also, hair analysis has advantages over other sample collection and storage techniques.

An aspect not well clarified in the scientific literature is the establishment of a baseline concentration for each toxic element in hair analysis, i.e., a concentration value indicating the zero with respect to human contamination from high levels of the toxic element in the environment. Certainly, the absence of reference baselines makes difficult the assessment of reported data, particularly when related to possible environmental pollution. For example, Mercury pollution in the Amazon because of gold mining activities, or Lead pollution in cities because of vehicles using leaded fuels.

Within the above scope, the objective of the present work was to compare concentrations of Mercury and Lead in hair among inhabitants from the scarcely populated Orinoco riverside in the Amazon state (Venezuela), where intensive small-scale gold mining is present; and inhabitants from the highly populated Caracas, a city where the use of unleaded fuels began in 2005 .

\section{MATERIAL AND METHODS}

A Perkin-Elmer Model ICP Optima 3000 inductively coupled plasma emission spectrometer was employed for the hair measurements. The operational parameters are described in Table 1. Standard $1000 \mathrm{ppm}$ solutions (Merck) of Lead and Mercury were employed to prepare the diluted solutions for calibration, which was carried out matching the same procedure employed for hair sample digestion. Detection limit obtained for both elements were very low: less than 0.1

Table 1 - Operational conditions of the spectrometer.

\begin{tabular}{ll}
\hline Frecuency of RF Generator & $40 \mathrm{MHz}$ \\
RF power & $1400 \mathrm{~W}$ \\
Nebulizer type & Meinhard concentric \\
Spray chamber & Scott type \\
Sampling & Peristaltic pump \\
Pump flow rate & $1.5 \mathrm{~mL} / \mathrm{min}$. \\
\hline Nebulizer gas flow rate & $0.50 \mathrm{~L} / \mathrm{min}$. \\
\hline Plasma gas flow rate & $12 \mathrm{~L} / \mathrm{min}$. \\
\hline Auxiliary gas flow rate & $0.50 \mathrm{~L} / \mathrm{min}$. \\
\hline Observation height above RF coil & $5 \mathrm{~mm}$ \\
\hline \multicolumn{2}{c}{ Wavelength employed (nm) } \\
\hline Pb & 220.353 \\
\hline Hg & 194.168 \\
\hline
\end{tabular}

$\mu$ g per gram of hair in each case. Repeated procedure of an analytical blank was conducted to ensure that there was no sample contamination from carryover. Previous to dissolution, hair was washed sequentially with acetone, water and $0.5 \%$ Triton X-100, followed by repeated rinsing with ultrapure water; dried at $100 \mathrm{C}$ in an oven overnight, and stored in a desiccators before weighting. Five $\mathrm{mL}$ of concentrated nitric acid (Suprapure) was added to each hair sample (600-1000 mg) placed inside beakers, and these were kept at room temperature overnight. Afterwards, the beakers were slowly heated to $100 \mathrm{C}$ and maintained at this temperature for 1 hour. After cooling to room temperature, $2 \mathrm{~mL}$ of hydrogen peroxide (Ultrapure) were added and the digest heated for a further $10 \mathrm{~min}$. For each sample, the mixture was cooled and quantitatively transferred to a $25 \mathrm{ml}$ flask with ultrapure water. The resulting solution was pumped to the spectrometer for analysis.

\section{RESULTS AND DISSCUSION}

In order to evaluate the accuracy of the present method, a powdered hair reference material, NIES No.5 (National Institute for Environmental Studies, Japan), was analysed employing the same procedure described above. The results were compared with the reported values, obtaining a good agreement (Table 2).

A total of 23 hair samples were collected at the Orinoco riverside communities of Samariapo, Isla Raton, and Raudal Danto, located about 70 to $100 \mathrm{Km}$ south of Puerto Ayacucho (main city in the Amazon state, Venezuela) and about 600 $\mathrm{Km}$ south of Caracas. Most samples belonged to Piaroas Indians. 20 hair samples were collected in Caracas from male individuals 16 to 58 years old, which were cut at the back of the head close to the scalp.

It should be pointed out that sample collections were carried out in Venezuela before leaded fuels were eliminated in 2005 .

The results of the hair analysis for Mercury and Lead concentrations are shown in Table 3, together with the relevant environmental characteristics. Standard deviations also shown

Table 2- Concentrations of Lead and Mercury elements in human hair (reference material NIES No.5).

\begin{tabular}{lcc}
\hline Element & $\begin{array}{c}\text { Reported } \\
(\mu \mathrm{g} / \mathrm{g})\end{array}$ & $\begin{array}{c}\text { Found } \\
(\mu \mathrm{g} / \mathrm{g})\end{array}$ \\
\hline $\mathrm{Pb}$ & 6.0 & $5.9 \pm 0.1$ \\
$\mathrm{Hg}$ & 4.4 & $4.7 \pm 0.4$ \\
\hline
\end{tabular}


in Table 3 indicate that differences between Caracas and Orinoco values are statistically reliable.

In contrast to the Orinoco sampling area, Caracas has a very high emission from spark combustion engines, many of which are large (e.g. V6 and V8), using high octane fuels (i.e. high Lead content in this particular case), common factors in Venezuela where automobile fuel is probably one of the world's cheapest (premium fuel is about 30 times cheaper than in the U.S.A.).

The relatively low Lead concentration in hair at the Orinoco sampling places $(7.7 \mu \mathrm{g} / \mathrm{g})$ could be related to a low level of Lead in the environment, which should be expected if it is assumed that most Lead must come from combustion engines using leaded fuels. Indeed, a very low number of engines actually operate in that area. In addition, most engines at the Orinoco riverside communities are marine outboard and truck engines, which normally use low octane fuels containing few or no Lead additives.

Accordingly, the above considerations are in agreement with the higher Lead concentration in the hair of Caracas citizens compared to the inhabitants of the Orinoco riverside (about 4 times higher, see table 3). Lead particles from automobile exhaust of one micron or smaller can remain airborne for a considerable period of time and, thereafter, can be adsorbed by human lung alveoli, entering the blood stream (Dept. Health and Social Sec., 1980), reaching bones and hair eventually. Another possibility is Lead ingestion by the consumption of food which has been in contact with air containing Lead particles.

Consequent of the above considerations, the baselines for Lead $(7.7 \mu \mathrm{g} / \mathrm{g})$ and for Mercury $(4.8 \mu \mathrm{g} / \mathrm{g})$ concentrations in hair analysis were established (Table 3). Coincidentally, these values are close to the values of the referenced hair employed (Table 2).

Table 3 - Concentrations of Lead and Mercury in human hair and other characteristics of two Venezuelan environments.

\begin{tabular}{lcc}
\hline Characteristic & $\begin{array}{c}\text { Orinoco } \\
\text { (Amazon state) }\end{array}$ & Caracas city \\
\hline $\begin{array}{l}\text { Human population } \\
\text { Artisan gold mining } \\
\text { Activity }\end{array}$ & Scarce & High \\
$\begin{array}{l}\text { Leaded fuel } \\
\text { Automobile activity }\end{array}$ & High & Nil \\
$\begin{array}{l}\text { Average hair } \\
\text { Pb concentration } \\
(\mu \mathrm{g} / \mathrm{g})\end{array}$ & High \\
$\begin{array}{l}\text { Average hair } \\
\mathrm{Hg} \text { concentration } \\
(\mu \mathrm{g} / \mathrm{g})\end{array}$ & $7.7 \pm 2.4$ & $30.3 \pm 12.4$ \\
\hline
\end{tabular}

The difference in Mercury concentration between the two places in this study (i.e., more than 3 times higher in the Orinoco zone than in Caracas, see table 3) suggests environmental pollution caused by artisan gold refining by miners in the Amazon rain forest (Barboza et al., 1995; Malm, 1998). Indeed, the low populated Venezuelan Amazon state is highly active in illegal gold mining.

River fish, as a dietrary mainstay, is most probably responsible for Mercury found in the Orinoco riverside people (Dolbec et al., 2001; Olivero et al., 2004; Pinheiro et al., 2005); as well as their drinking the river water.

\section{CONCLUSIONS}

Hair analysis has presently proven to be an appropriate tool for locating Mercury or Lead in polluted environments, particularly when baselines for the concentration of these elements in hair are established under the same experimental conditions. According to the average concentration values of the two regions presently studied, the Amazon state and Caracas can be considered antagonistic environments as found through hair analysis, i.e., the former has low levels of Lead but high levels of Mercury, and the later has low levels of Mercury but high levels of Lead.

\section{LITERATURE CITED}

Barbosa A.C.; Boischio A.A.; East G.A.; Ferrari I.; Gonçalves A.; Silva P.; Cruz, T. 1995. Mercury Contamination in the Brazilian Amazon: Environmental and Occupational Aspects. Water, Air \& Soil Pollution, 80: 109-121.

Bencko, V. 1995. Use of Human Hair as a Biomarker in the Assessment of Exposure to Pollutants in Occupational and Environmental Settings. Toxicology, 101:29-39.

Contiero, E.; Folin, M. 1994 Trace Elements Nutritional Status: Use of Hair as a Diagnostic Tool. Biol. Trace Element Research. 40:151-160.

Department of Health and Social Security. 1980. Lead and Health, HMSO, London, 129 pp.

Dolbec, J.; Mergler, D.; Larribe, F.; Roulet, M.; Lebel, J.; Lucotte, M. 2001. Sequential analysis of hair mercury levels in relation to fish diet of an Amazonian population, Brazil. Science of the Total Environment, 271:87-97.

Hac E.; Krechniak, J. 1996. Lead levels in bone and hair of rats treated with lead acetate. Biological Trace Element Research, 52: 293-301.

Katz, S.A.; Katz, R.B. 1992. Use of hair Analysis for Evaluating Mercury Intoxication of the Human Body: a Review. Journal of Applied Toxicology, 12:79-84.

Malm, O. 1998. Gold mining as a source of mercury exposure in the Brazilian Amazon. Environmental Research, Section A, 77:73-78. 
Olivero, J.; Johnson, B.; Mendoza, C.; Paz, R.; Olivero, R. 2004. Mercury in the aquatic environment of the village of Caimito at the Mojana Region, north of Colombia. Water Air Soil Pollution, 159: 409-420.

Pinheiro, M.C.N.; Muller, R.C.S.; Sarkis, J.E.; Vieira, J.L.F.; Oikawa, T.; Gomes, M.S.V.; Guimaraes, G.A.; do Nascimento, J.L.M.; Silveira, L.C.L. 2005. Mercury and selenium concentrations in hair samples of women in fertile age from Amazon riverside communities. Science of the Total Environment, 349: 284-288.
Taylor, A. 1986. Usefulness of measurements of trace elements in hair. Annals of Clinical Biochemistry, 23: 364-378.

Recebido em 23/08/2007

Aceito em 17/02/2009 